\title{
Assessing the Validity of Pyrethroid Treated Bed Net in the Curb of the Spread of Malaria Disease. A Case Study of Ijero Towhship, Ijero LGA of Ekiti State, Nigeria
}

\author{
Sam-Ijadele Oluwakemi Ifedayo \\ Ekiti State College of health Sciences and Technology Ijero \\ Department of Environmental Health. \\ Author \& Corresponding Author
}

Co-Authors

Makanjuola Bosede Christianah,

Ekiti State College of Health Sciences and Technology Ijero Department of Environmental Health

Bello Mojisola

Ekiti State College of health Sciences and TechnologyIjero Department of Environmental Health.
Oluwatuyi SHEGUN Victor

Ekiti State College of health Sciences and Technology Ijero

Department of Public Health.

Adewumi Michael Onasanmi,

Ekiti State College of Health Sciences and Technology Ijero Department of Environmental Health

\author{
Oluwatuyi Mayowa Funmilayo \\ Ekiti State College of health Sciences and Technology Ijero \\ Department of Health Information Management.
}

\begin{abstract}
This research work had shed light on assessing the effectiveness of pyrethroids impregnated treated bed nets in the curbing of the spread of Malaria disease in Ijero township in Ekiti State. This study focused on assessing efficiency of mosquito treated bed nets LLITNs, acknowledge people's attitude towards the use of the LLITNs and to determine the resistance level of mosquitoes to pyrethroid impregnated treated bed nets. The methodology involved in this research entailed the use of descriptive study research where four objectives were constructed along with five research questions. From the total population of the area $(167,632)$, two hundred was picked as sample size through simple random sampling in which questionnaires were distributed to the four political wards, which includes ward $A, B, C$ and $D$ respectively. And thirty questionnaires were also administered to the three health centres in Ijero Township. They were designed for the purpose of collecting necessary information on efficacy of pyrethroids impregnated bed nets in curbing of Malaria spread while also making use of secondary data from health institutions in Ijero Township and information gathered were analysed and presented in tables using simple percentage and also presented in graphs. The researcher concluded that, the
\end{abstract}

attitude of the users towards the use of LLITNs is against the manufacturers instruction, and also the effectiveness of LLITNs is partial due to the complaints about the heat and other inconveniences experienced under the nets thereby discourages the use of the LLITNs. Recommendation were based on findings: that in places where these nets have been distributed people should not personally administer pyrethroid as it can enhance pest resistance which reduces the potency and validity of the net. Other measures which include the use of varied insecticides spray to ensure the efficiency of LLITNs.

Keywords:- Malaria: Insecticide; LLITNs; Resistance; Prevalence.

\section{INTRODUCTION}

Malaria is caused in humans by five species of singlecell, eukaryotic Plasmodium parasites (mainly Plasmodium falciparum and Plasmodium vivax) that are transmitted by the bite of Anopheles mosquitoes. In humans, malaria parasites grow and multiply first in the liver cells and then exponentially in the red blood cells. It is the blood stage of the parasite lifecycle that causes the symptoms of malaria in 
humans. Malaria is usually classified as asymptomatic, uncomplicated or severe. Asymptomatic malaria can be caused by all Plasmodium species; the patient has circulating parasites but no symptoms. Uncomplicated malaria can be caused by all Plasmodium species. Symptoms generally occur 7-10 days after the initial mosquito bite. Symptoms are non-specific and can include fever, moderate to severe shaking chills, profuse sweating, headache, nausea, vomiting, diarrhoea and anaemia, with no clinical or laboratory findings of severe organ dysfunction. Severe malaria is usually caused by infection with Plasmodium falciparum, though less frequently can also be caused by Plasmodium vivax or Plasmodium knowlesi. Complications include severe anaemia and end-organ damage, including coma (cerebral malaria), pulmonary complications (for example, oedema and hyperpnoeic syndrome) and hypoglycaemia or acute kidney injury. Severe malaria is often associated with hyperparasitaemia and is associated with increased mortality. Learn more about the epidemiological definition of severe malaria on the Severe Malaria Observatory. Malaria is caused by plasmodium parasites. The parasites are spread to people through the bites of infected female anopheles mosquitoes, called "malaria vector". There are five parasites species that cause malaria in humans, and 2 of these species - P.falciparum and P.vivax - pose the greatest threat. In 2015, approximately 3.2billion people nearly half of the world's population were at risk of malaria. Most malaria cases and deaths occur in sub-Saharan Africa. However, Asia, Latin America, and, to a lesser extent the middle east and parts of Europe, are also at risk. In 2015, 97 countries and territories had ongoing malaria transmission. Some population groups are at considerably higher risk of contracting malaria, and developing severe disease, than others. These include infants, children under five years of age, pregnant women and patience with HIV/AIDS, as well as non-immune migrants, mobile population and travellers. National malaria programmes need to take special measures to protect these population growth from malaria infection, taking into consideration their specific circumstances. According to the latest WHO estimates, released in September 2015, there were 214million cases malaria in 2015 and 438,000 deaths. Between 2000 and 2015, malaria incidence fell by $37 \%$ globally; during the same period, malaria mortality rates decreased by $60 \%$. An estimated 6.2million malaria deaths have been averted globally since 2000. Sub-Saharan Africa continues to carry a disproportionately high share of global malaria burden. In 2015 , the region was home to $89 \%$ of malaria cases and $91 \%$ of malaria deaths. Some 15 countries - mainly in subSaharan Africa account for $80 \%$ of malaria cases and $78 \%$ dead globally. Since 2000, the decline in malaria incidence in these 15 countries (32\%) has lagged behind that of other countries globally (54\%). In area with high transmission of malaria, children under 5 are particularly susceptible to infection, illness and death; more than two thirds (70\%) of all malaria deaths occur in this age group. Between 2000 and 2015 , the under -5 malaria death rate fell by $65 \%$ globally, translating into an estimated 5.9million child lives saved. An insecticide-treated net is a mosquito net that repels, disables and/or kills mosquitoes coming into contact with insecticide on the netting materials. There are two categories of LLITNS; Conventionally treated nets and long-lasting insecticidal nets: A conventionally treated net is a mosquito net that has been treated by dipping in a WHO recommended insecticide. To ensure its continued insecticidal effect, the net should be re-treated after three washes, or at least once a year. A long-lasting insecticidal net is a factory-treated mosquito net made with netting materials that has insecticide incorporated within or bound around the fibres. The ne must retain its effective biological activity without re-treatment for at least $20 \mathrm{WHO}$ standard washes under laboratory conditions and three years of recommended use under field conditions. All mosquito nets act as a physical barrier, preventing access by vector mosquitoes and thus providing personal protection against malaria to the individual(s) using the nets. Pyrethroid insecticides, which are used to treat nets, have an exciterepellent effect that adds a chemical barrier to the physical one, further reducing human-vector contact and increasing the protective efficacy of the mosquito vectors that come into contact with the ITN. By reducing the vector population in this way, LLITNs, when used by a majority of the target population, provide protection for all people in community, including those who do not themselves sleep under nets.

A recent study has shown that relatively modest coverage (around 60\%) of all adults and children can achieve equitable community wide benefits.

\section{OBJECTIVE OF THE STUDY}

The objective of this study is to;

- gauge efficiency of mosquito treated bed net LLITNs

- Identify rate or extent distribution of mosquito treated bed net

- Acknowledge people's attitude in the utilization of LLITNs.

- Determine resistance level of mosquito to pyrethroid impregnated treated bed net 


\section{STUDY AREA}

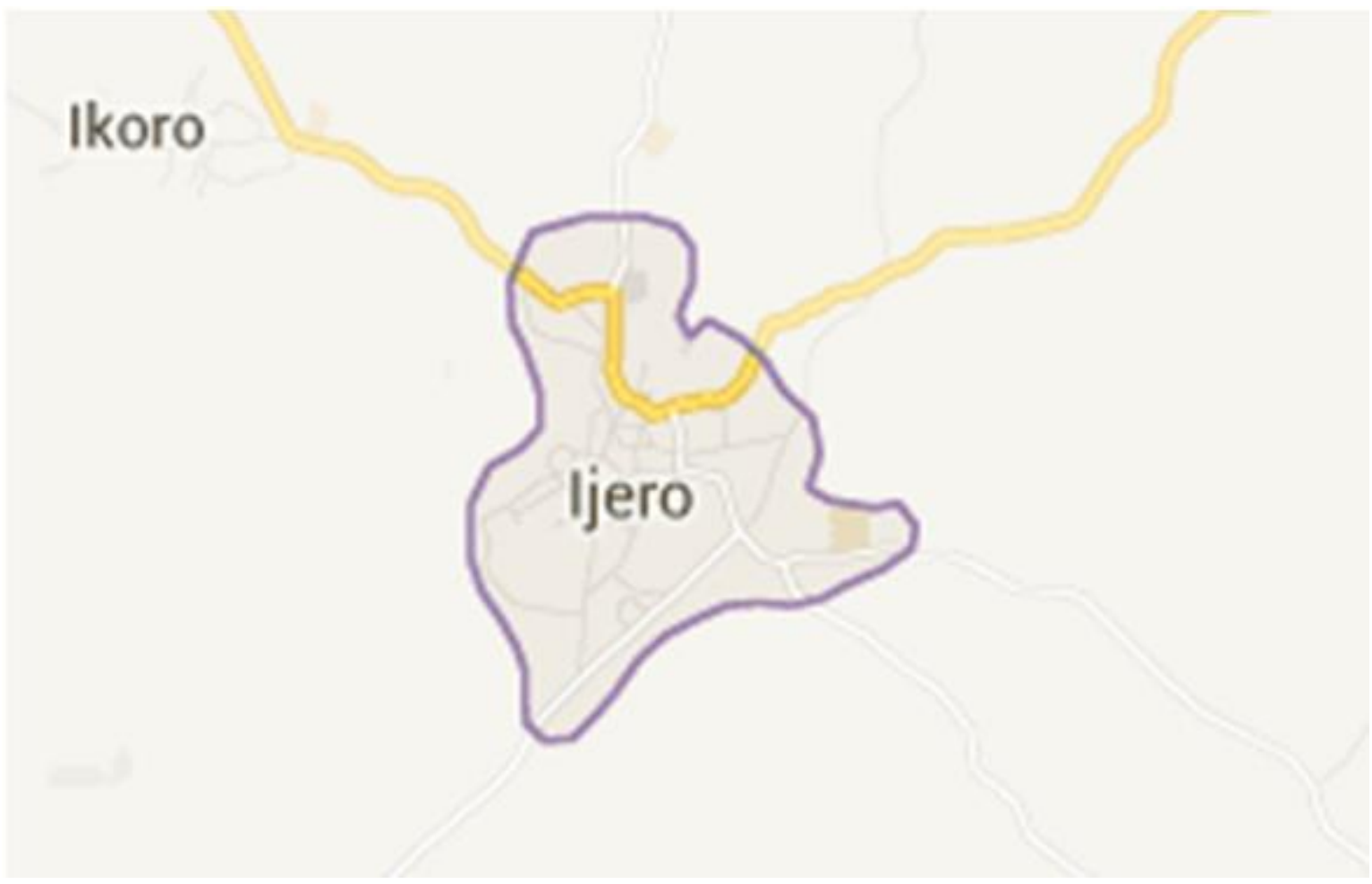

- Population of Ijero Township is 167,632 people

- Latitude: $7.81^{0} \mathrm{~N}$

- Longitude $5.07^{\circ} \mathrm{E}$

- Elevation/Attitude: $466 \mathrm{~m}$

- Temperature: $21.8^{0} \mathrm{C} / 69.8^{0} \mathrm{~F}$

- Wind: $2.3 \mathrm{~m} / \mathrm{s}$ south-west

- Cloudiness: $95.3 \%$

- Humidity: $96.8 \%$

- Atmospheric pressure: $1015.0 \mathrm{hpa}$

- Precipitation: $0.9 \mathrm{~mm}$

\section{METHODOLOGY AND SAMPLING TECHNIQUES}

A descriptive, cross-section technique was used randomly to select different people from the four political wards and also from the three health center's in Ijero township in order to examine various factors responsible for malaria infection despite the use of LLITNs.

\section{Sampling}

Simple random sampling was adopted to select 230 respondents, 200 from the four wards in the community and 30 respondents health workers from the three health centres in the town. Who were given the questionnaires. The respondents includes literate and illiterate, youths and adults collected LLITNs during the mass distribution in Ijero township.

\section{Instrument Design}

Questionnaire was designed to elicit some vital information from the respondents as well as observation, personal interview, focus group and secondary data sourced from the head quarter of the three health centres in the town, Odo - Ese Maternity centre. To ensure accuracy in the data collected.

\section{* Method of Data Collection \\ Observation}

The researcher observed that the incidence rate of malaria infection is high, despite the mass distribution of LLITNs.

\section{$>$ Personal Interviews}

This method was used in complimenting the capacity of the questionnaire administered. It assisted the researcher to confirm some answers of interest with a view to reach a correct conclusion and also assisted in constructive recommendation by the researcher at the end of the researcher work.

\section{Focus Group}

The researcher adopted this method in order to compliment the researcher work, whereby people were gathered in an interactive group setting where participant are free to talk to ask about their perceptions, opinions, belief, concept and ideas with other group members.

\section{Secondary Data}

Data was sourced from headquarters of three health centres in Ijero Township to ascertain prevalence of Malaria causes while identifying the various types of nets supplied for the past 10 years. 


\section{DATA ANALYSIS AND PRESENTATION OF THE RESULTS}

TABLE A: SOCIO-DEMOGRAPHIC DATA

\begin{tabular}{|c|c|c|}
\hline AGE & FREQUENCY & PERCENTAGE $\%$ \\
\hline $18-27$ & 40 & 20 \\
\hline $28-37$ & 60 & 30 \\
\hline $38-47$ & 50 & 25 \\
\hline $48-57$ & 35 & 17.5 \\
\hline 58 and above & 15 & 7.5 \\
\hline TOTAL & 200 & $100 \%$ \\
\hline SEX & FREQUENCY & PERCENTAGE $\%$ \\
\hline Male & 12 & 06 \\
\hline Female & 188 & 94 \\
\hline TOTAL & 200 & $100 \%$ \\
\hline OCCUPATIONAL STATUS & FREQUENCY & PERCENTAGE\% \\
\hline Public Servants & 60 & 30 \\
\hline Students & 42 & 21 \\
\hline Artisan & 48 & 24 \\
\hline Traders & 50 & 25 \\
\hline TOTAL & 200 & $100 \%$ \\
\hline EDUCATIONAL STATUS & FREQUENCY & PERCENTAGE\% \\
\hline Primary School & 30 & 15 \\
\hline Secondary School & 52 & 26 \\
\hline Tertiary level & 70 & 35 \\
\hline None & 48 & 24 \\
\hline TOTAL & 200 & $100 \%$ \\
\hline MARITAL STATUS & FREQUENCY & PERCENTAGE\% \\
\hline Single & 65 & 32 \\
\hline Married & 106 & 53 \\
\hline Widow & 10 & 05 \\
\hline Divorce & 10 & 05 \\
\hline Separated & 08 & 04 \\
\hline TOTAL & 200 & $100 \%$ \\
\hline
\end{tabular}

Survey, 2015

The above table revealed the socio- demographic variables of respondents as well as Age distribution, Sex, Occupational status, Educational status and Marital status. It is confirmed that $20 \%$ are of age range $18-27,30 \%$ are of age range $28-37$ years,50 respondents are representing $25 \%$ which are of age range 38-47,17.5\% are of age range $48-57$ years, while $7.5 \%$ are of age 58 and above. 12 respondents are representing 6\% are Male, while 188 respondents are representing 94\% are Female, also, 60 respondents are representing 30\% are public servants, 42 respondents are representing $21 \%$ are Students, $24 \%$ major in Artisans, 25\% are Traders. Also,30 respondents are representing 15\% are primary school leaver, 52 respondents are representing $26 \%$ are secondary school leaver, 70 respondents are representing $35 \%$ are tertiary school leaver, while 48 respondents are representing $24 \%$ are illiterate and finally on this table A,66 respondents are representing 33\% are Single, 106 respondents are representing 53\% are Married, 10 respondents are representing 5\% of both widow and divorce respectively, while 8 respondents are representing $4 \%$ are separated. 
TABLE B: GENERAL KNOWLEDGE ABOUT LLITNS

\begin{tabular}{|c|c|c|c|}
\hline QUESTIONS & RESPONSES & FREQUENCY & PERCENTAGE\% \\
\hline \multirow{3}{*}{$\begin{array}{l}\text { 1. Have you ever heard of } \\
\text { insecticide treated bed net? }\end{array}$} & Yes & 195 & 97.5 \\
\hline & No & 05 & 2.5 \\
\hline & Total & 200 & $100 \%$ \\
\hline \multirow{6}{*}{$\begin{array}{l}2 . \quad \text { How did you get } \\
\text { information on the campaign } \\
\text { and distribution of LLITNs? }\end{array}$} & Town announcers & 18 & 09 \\
\hline & Media(TV, Radio & 140 & 70 \\
\hline & c. Neighbour/friend & 12 & 06 \\
\hline & $\begin{array}{l}\text { d. Traditional and religions } \\
\text { institution }\end{array}$ & 25 & 12.5 \\
\hline & e. Not aware & 05 & 2.5 \\
\hline & TOTAL & 200 & $100 \%$ \\
\hline \multirow{3}{*}{$\begin{array}{l}3 . \quad \text { Do you know the } \\
\text { importance of LLITNs }\end{array}$} & Yes & 195 & 97.5 \\
\hline & No & 05 & 2.5 \\
\hline & TOTAL & 200 & $100 \%$ \\
\hline \multirow{4}{*}{$\begin{array}{l}4 . \quad \text { What type of net do } \\
\text { you use? }\end{array}$} & Treated & 110 & 55 \\
\hline & Non-treated & 15 & 7.5 \\
\hline & none & 75 & 37.5 \\
\hline & TOTAL & 200 & $100 \%$ \\
\hline
\end{tabular}

\section{TABLE B}

This table shows the general knowledge about LLITNs,195 respondents are representing 97.5\% said they have heard about LLITNs and 5 respondents are representing 2.5\% said that they were not aware about LLITNs, 195 respondents are representing 97.5\% said that they know the importance of LLITNs. Out of 195 respondents that know the importance of LLITNs, 110 respondents are representing 55\% said that they are using treated bed nets, 15 respondents are representing $7.5 \%$ said that they are using Non- treated bed nets, while 75 respondents are representing 37.5\% said that they do not use LLITNs in which some of them do collect LLITNs during the mass distribution but do not use for any purpose.

TABLE C: DOES THE USE OF LLITNS EFFECTIVELY CONTROL MALARIA VECTOR

\begin{tabular}{|c|c|c|c|}
\hline QUESTIONS & RESPONSES & FREQUENCY & PERCENTAGE\% \\
\hline \multirow{3}{*}{$\begin{array}{l}1 . \text { Do you collect LLITNs } \\
\text { during the mass distribution? }\end{array}$} & Yes & 137 & 68.5 \\
\hline & No & 63 & 31.5 \\
\hline & TOTAL & 200 & 100 \\
\hline \multirow{3}{*}{$\begin{array}{l}2 . \quad \text { Is the use of LLITNs } \\
\text { effective in the prevention and control } \\
\text { of malaria infection? }\end{array}$} & Yes & 52 & 38 \\
\hline & No & 85 & 62 \\
\hline & TOTAL & 137 & $100 \%$ \\
\hline \multirow{6}{*}{$\begin{array}{l}3 . \quad \text { If no, how often do you } \\
\text { come down with malaria infection? }\end{array}$} & Every month & 13 & 15.3 \\
\hline & Twice in three months & 31 & 36.5 \\
\hline & Every three months & 16 & 18.8 \\
\hline & Twice in six months & 13 & 15.3 \\
\hline & Twice in a year & 12 & 14.1 \\
\hline & TOTAL & 85 & $100 \%$ \\
\hline \multirow{7}{*}{$\begin{array}{l}\text { 4. What alternative control } \\
\text { measure do you suggest? }\end{array}$} & Environmental sanitation & 10 & 12 \\
\hline & Indoor spraying & 38 & 45 \\
\hline & Swatting & - & - \\
\hline & Screening of the opening & 12 & 14 \\
\hline & Physical hand clapping & - & - \\
\hline & All of the above & 25 & 29 \\
\hline & TOTAL & 85 & $100 \%$ \\
\hline \multirow{4}{*}{$\begin{array}{l}5 . \quad \text { Do you think these methods } \\
\text { mentioned above would effectively } \\
\text { control malaria vector? }\end{array}$} & Yes & 70 & 32 \\
\hline & No & - & - \\
\hline & Partially & 15 & 18 \\
\hline & TOTAL & 85 & $100 \%$ \\
\hline \multirow{3}{*}{$\begin{array}{l}\text { 6. Do you support government } \\
\text { in continuation of distribution of } \\
\text { LLITNs? }\end{array}$} & Yes & 35 & 17.5 \\
\hline & No & 165 & 82.5 \\
\hline & TOTAL & 200 & $100 \%$ \\
\hline
\end{tabular}

Source: Field Survey, 2015. 
TABLE C

This table represent the effectiveness of LLITNs in control of malaria vector. 137 respondents are representing $68.5 \%$ said that they do collect LLITNs during the mass distribution, out of which 52 respondents are representing $38 \%$ said that the use of LLITNs are valid in the curb of the spread of malaria and 85 respondents are representing $62 \%$ said otherwise. Out of 85 respondents are representing $62 \%$ that said the LLITNs are not efficacious in curbing the spread of malaria',13 respondents are representing $15.3 \%$ do come down with malaria infection in every month, 31 respondents are representing $36.5 \%$ do come down with malaria infections twice in three month, 16 respondents are representing $18.8 \%$ do come down with malaria infection every three months, 13 respondents are representing $15.3 \%$ do come down with malaria infection twice in six months and 12 respondents are representing $14.1 \%$ do come down with malaria infection twice in a year. The same 85 respondents are representing $62 \%$ said that they have different alternative measure in controlling malaria infection, 10 respondents are representing $12 \%$ said that Environmental sanitation will surely control malaria infection, 38 respondents are representing $45 \%$ said that the indoor spraying is the best measure for them in controlling malaria vectors, 12 respondents are representing $14 \%$ said that they prefer screening of the openings, and 25 respondents are representing $29 \%$ said that they support all the aforementioned measures in the control of malaria vectors/infections, 70 respondents are representing $82 \%$ said that the aforementioned measure will definitely control malaria infection and 15 respondents are representing $18 \%$ said that the measures will control it partially. And last question on this table, out of 200 respondents,35 respondents are representing $17.5 \%$ do support government in continuation of the distribution of LLITNs and 165 respondents are representing $82.5 \%$ do not support government in continuation of the distribution of LLITNs.

TABLE D: DO THE USERS STRICTLY ADHERE TO THE MANUFACTURERS INSTRUCTIONS ON THE USE OF LLITNS

\begin{tabular}{|c|c|c|c|}
\hline QUESTIONS & RESPONSES & FREQUENCY & PERCENTAGE\% \\
\hline \multirow{3}{*}{$\begin{array}{l}\text { 1. Does the health facilitator } \\
\text { health educate you on the use of } \\
\text { LLITNs? }\end{array}$} & Yes & 109 & 80 \\
\hline & No & 28 & 20 \\
\hline & TOTAL & 137 & $100 \%$ \\
\hline \multirow{3}{*}{$\begin{array}{l}2 . \quad \text { Do you spread it out } \\
\text { under the shade before use? }\end{array}$} & Yes & 125 & 91 \\
\hline & No & 12 & 9 \\
\hline & TOTAL & 137 & $100 \%$ \\
\hline \multirow{6}{*}{$\begin{array}{l}3 . \quad \text { How many days do you } \\
\text { spread it out before use? }\end{array}$} & a) 1 day & 07 & 05 \\
\hline & 2 days & 18 & 13 \\
\hline & 3 days & 80 & 58 \\
\hline & 5 days & 20 & 15 \\
\hline & None & 12 & 09 \\
\hline & TOTAL & 137 & $100 \%$ \\
\hline \multirow[t]{5}{*}{ 4. $\quad$ How do you use the net? } & I hang it on my bed & 72 & 52.6 \\
\hline & I hang it on my window & 30 & 21.9 \\
\hline & I hang it on as door net & 25 & 18.2 \\
\hline & d) $\quad$ I use it in my garden & 10 & 7.4 \\
\hline & TOTAL & 137 & $100 \%$ \\
\hline
\end{tabular}

Survey, 2015

\section{TABLE D}

The above shows how the users strictly adhere to the manufacturer instructions on the use of LLITNs. Out of the 137 respondents that collect LLITNs during the mass distribution 109 respondents are representing $80 \%$ said that health facilitator health educate them on the use of LLITNs and 28 respondents are representing $20 \%$ said that health facilitator do not health educate them, 125 respondents are representing $91 \%$ said they do spread it out under the shade before use, and 12 respondents are representing $9 \%$ said that they do not spread it out before use. Also 7 respondents are representing 5\% said that they spread it out just for a day, 18 respondents are representing 13\% said that they spread it out just for two days, 80 respondents are representing $58 \%$ strictly adhere to the manufacturers instruction by spreading it out for good three days before use, 20 respondents are representing $15 \%$ said that they spread it out for five days before use and 12 respondents are representing $9 \%$ failed to spread it out before use. And finally on these table discussion on the use of the net are hereby highlighted below, 72 respondents are representing $52.6 \%$ do hang the net on their beds, 30 respondents are representing $21.9 \%$ hang it on their windows, 25 respondents are representing $18.2 \%$ hang it as door net, and 10 respondents are representing $7.3 \%$ do use it in their gardens. 
ISSN No:-2456-2165

TABLE E: IS THERE ANY POSSIBILITY THAT MOSQUITOES CAN DEVELOP RESISTANCE TOWARDS PYRETHROID?

\begin{tabular}{|c|c|c|c|}
\hline QUESTIONS & RESPONSES & FREQUENCY & PERCENTAGE\% \\
\hline \multirow{3}{*}{$\begin{array}{l}\text { 1. Do you make use of LLITNs all the } \\
\text { time? }\end{array}$} & Yes & 127 & 63.5 \\
\hline & No & 73 & 36.5 \\
\hline & TOTAL & 200 & $100 \%$ \\
\hline \multirow{6}{*}{$\begin{array}{l}2 . \quad \text { How long have you being collecting } \\
\text { LLITNs? }\end{array}$} & a) 12 months ago & 20 & 10 \\
\hline & b) 24 months ago & 42 & 21 \\
\hline & c) 36 month ago & 25 & 12.5 \\
\hline & d) Above 3 years ago & 50 & 25 \\
\hline & e) I do not collect & 63 & 31.5 \\
\hline & TOTAL & 200 & $100 \%$ \\
\hline \multirow{3}{*}{$\begin{array}{l}\text { 3. Do you normally sow the torn part of } \\
\text { the nets? }\end{array}$} & Yes & 88 & 69.3 \\
\hline & No & 39 & 30.7 \\
\hline & Total & 127 & $100 \%$ \\
\hline \multirow{3}{*}{$\begin{array}{l}\text { 4. Do you re-treats the LLITNs as at } \\
\text { when due? }\end{array}$} & Yes & - & - \\
\hline & No & 127 & 100 \\
\hline & TOTAL & 127 & $100 \%$ \\
\hline \multirow{3}{*}{$\begin{array}{l}5 . \\
\text { experience mosquito bite under the net? }\end{array}$} & Yes & 49 & 68 \\
\hline & No & 23 & 32 \\
\hline & Total & 72 & $100 \%$ \\
\hline \multirow{3}{*}{$\begin{array}{l}6 . \text { If yes, do you think the vector has } \\
\text { developed resistance to the chemical used in } \\
\text { treating the net? }\end{array}$} & Yes & 46 & 93.9 \\
\hline & No & 03 & 6.1 \\
\hline & Total & 49 & $100 \%$ \\
\hline
\end{tabular}

Survey, 2015

\section{TABLE E}

The above revealed that is there any possibility that mosquitoes can develop resistance towards pyrethroid. Out of 200 respondents, 127 respondents are representing $63.5 \%$ do make use of LLITNs all the time and 73 respondents are representing $36.5 \%$ do not make use of LLITNs all the time, on the collection of LLITNs, 20 respondents are representing $10 \%$ said that they collected LLITNs a year ago, 42 respondents are re[presenting $21 \%$ said that they have been collecting LLITNs for the past two years, 25 respondents are representing $12.5 \%$ said that it has been three years since they have been collecting LLITNs, 50 respondents are representing $25 \%$ said it has been more than three years they have been collecting LLITNs, and 63 respondents are representing $31.5 \%$ do not collect LLITNs at all. Out of 127 respondents that make use of LLITNs, 88 respondents are representing $69.3 \%$ do sow the torn part of the nets and 39 respondents are representing $30 . \%$ do not sow the torn part of the nets, the whole 127 respondents are representing $100 \%$ said that they do not re-treat the nets as at when due. Out of 72 respondents that hang the net on their beds, 49 respondents are representing 68\% said despite the use of LLITNs they still experience mosquito bite under the nets, and 23 respondents are representing 32\% said they do not experience mosquito bite under the nets. And finally on this table, 46 respondents are representing $93.9 \%$ think there is resistance build up by the vector to the chemical used in treating the net, and 3 respondents are representing $6.1 \%$ said otherwise.

TABLE F: ARE THE HEALTH WORKERS AND FACILITATORS ON THE CAMPAIGN AND DISTRIBUTION OF LLITNS COMPETENT ENOUGH FOR THE JOB

\begin{tabular}{|l|l|l|l|}
\hline QUESTIONS & RESPONSES & FREQUENCY & PERCENTAGE\% \\
\hline \multirow{2}{*}{$\begin{array}{l}\text { you promptly? } \\
\text { Does the health facilitator attend to }\end{array}$} & Yes & 82 & 60 \\
\cline { 2 - 4 } & No & 55 & 40 \\
\cline { 2 - 4 } $\begin{array}{l}2 . \\
\text { number of LLITNs? }\end{array}$ & TOTAL & $\mathbf{1 3 7}$ & $\mathbf{1 0 0 \%}$ \\
\hline \multirow{3}{*}{$\begin{array}{l}3 . \quad \text { Are the health facilitators or health } \\
\text { workers sentimental in the distribution of } \\
\text { the nets? }\end{array}$} & Yes & 102 & 74.5 \\
\cline { 2 - 4 } & No & 35 & 25.5 \\
\cline { 2 - 4 } & TOTAL & $\mathbf{1 3 7}$ & $\mathbf{1 0 0 \%}$ \\
\hline
\end{tabular}

Survey, 2015

TABLE F

This above discusses competency and capability of health workers and facilitators on the campaign and distribution of LLITNs. Out of 137 respondents that collected LLITNs during the mass distribution, 82 respondents are representing $60 \%$ said that the health workers and facilitators attended to them promptly and 55 respondents are representing $40 \%$ said that they were not 
attended to very well, also 102 respondents are representing 74.5\% said that they were given the expected number of LLITNs and 35 respondents are representing $25.5 \%$ said that they were not given the expected number of LLITNs and finally on this table, 55 respondents are representing $40 \%$ said that the health workers and facilitators are not sentimental in the distribution of LLITNs and 82 respondents are representing $60 \%$ said that the health workers and facilitators are sentimental in the distribution of the LLITNs.

\section{HEALTH WORKERS}

N.B: This section is strictly for the health workers, Thirty questionnaires were distributed to the three Health Centres in the area, which is in Ijero Township.

TABLE A: DEMOGRAPHIC INFORMATION OF HEALTH WORKERS

\begin{tabular}{|l|l|l|l|}
\hline S/N & SEX & FREQUENCY & PERCENTAGE \\
\hline $\mathbf{1}$ & Male & 06 & 20 \\
\hline & Female & 24 & 80 \\
\hline & Total & $\mathbf{3 0}$ & $\mathbf{1 0 0 \%}$ \\
\hline $\mathbf{2}$ & DESIGNATION/RANK & FREQUENCY & PERCENTAGE \% \\
\hline & CHO & 3 & 10 \\
\hline & CHEW & 10 & 33 \\
\hline & Medical Records & 8 & 27 \\
\hline & JCHEW & 9 & 30 \\
\hline & Total & $\mathbf{3 0}$ & $\mathbf{1 0 0}$ \\
\hline
\end{tabular}

\section{QUESTIONNAIRE FOR THE HEALTH WORKERS}

\section{TABLE A QUESTIONNAIRE II}

This table discusses the bio-data of health workers that are involved in the campaign and distribution of LLITNs. 6 respondents are representing $20 \%$ are male, while 24 respondents are representing $80 \%$ are female. Designation or rank of the respondents (health workers) involved in the distribution of the nets in the three health centers at Ijero township are hereby enlisted: they are 3 respondents are $\mathrm{CHO}$ representing $10 \%$ out of the total responding population, 10 respondents are representing $33 \%$ are CHEW, 8 respondents are representing $27 \%$ are medical record officers, while 9 respondents are representing $30 \%$ are JCHEW.

Table B: Are the Health Workers, Facilitators and Government helpful in promoting and enhancing a successful malaria control programme.

\begin{tabular}{|c|c|c|c|c|}
\hline $\mathbf{S} / \mathbf{N}$ & QUESTION & RESPONSES & FREQUENCY & PERCENTAGE \\
\hline \multirow[t]{3}{*}{1} & \multirow{3}{*}{$\begin{array}{l}\text { Do you have enough supply } \\
\text { from the source? }\end{array}$} & Yes & 30 & 100 \\
\hline & & No & - & - \\
\hline & & Total & 30 & 100 \\
\hline \multirow[t]{3}{*}{2} & \multirow{3}{*}{$\begin{array}{l}\text { Is the turnout for the } \\
\text { collection of the nets } \\
\text { impressive? }\end{array}$} & Yes & 30 & 100 \\
\hline & & No & - & - \\
\hline & & Total & 30 & 100 \\
\hline \multirow[t]{3}{*}{3} & $\begin{array}{l}\text { Do you give them the nets } \\
\text { as required base on the } \\
\text { numbers of family size? }\end{array}$ & Yes & 30 & 100 \\
\hline & & No & - & - \\
\hline & & Total & 30 & 100 \\
\hline \multirow[t]{3}{*}{4} & $\begin{array}{l}\text { Do you have excess after } \\
\text { distribution? }\end{array}$ & Yes & 30 & 100 \\
\hline & & No & - & - \\
\hline & & Total & 30 & 100 \\
\hline \multirow[t]{4}{*}{5} & $\begin{array}{l}\text { If yes, what do you do with } \\
\text { the excess? }\end{array}$ & a). Keep in the store & - & - \\
\hline & & b. Return to the source & 30 & 100 \\
\hline & & c. Sell & - & - \\
\hline & & Total & 30 & 100 \\
\hline
\end{tabular}

TABLE B

This table discusses the impact of health workers, health facilitators and government in achieving a successful malaria control programme. All the 30 respondents are representing $100 \%$ said that they have enough supply from the source, also 30 respondents are representing $100 \%$ said that the turn out for the collection of the LLITNs are impressive, 30 respondents are 
representing $100 \%$ said that they give the individual the net as required base on the numbers of family size, and the whole 30 respondents are representing 100\% said they do have excess after the distribution. The entire 30 respondents are representing $100 \%$ said that when there is excess/uncollected nets they do return it to the source of supply which is society for family health. So also, in this table the following questions were asked and answered by the CHO's (matron) from the three health centres in Ijero township:

SECONDARY DATA

DATA RETRIEVED FROM THE THREE HEALTH CENTRES AT IJERO TOWNSHIP ARE ELUCIDATED BELOW:

1. DATA RETRIEVED FROM ODO -ESE HEALTH CENTRE (HEADQUARTERS) OF THE THREE HEALTH CENTRES ARE HEREBY TABULATED BELOW:

A: CHILDREN UNDER 5 YEARS

\begin{tabular}{|c|c|c|c|c|}
\hline YEAR (JAN-DEC) & MALE & FEMALE & PERCENTAGE (MALE) & $\begin{array}{c}\text { PERCENTAGE } \\
\text { (FEMALE }\end{array}$ \\
\hline 2005 & 32 & 57 & 10 & 14 \\
\hline 2006 & 57 & 60 & 18 & 15 \\
\hline 2007 & 44 & 50 & 12 & 11 \\
\hline 2008 & 38 & 44 & 13 & 11 \\
\hline 2009 & 41 & 45 & 5 & 6 \\
\hline 2010 & 33 & 44 & 6 & 7 \\
\hline 2011 & 16 & 22 & 6 & 6 \\
\hline 2012 & 18 & 26 & 5 & $\mathbf{1 1}$ \\
\hline 2013 & 17 & 24 & $\mathbf{1 0 0 \%}$ & 6 \\
\hline 2014 & 14 & $\mathbf{3 1 0}$ & $\mathbf{3 9 4}$ & \\
\hline Total & & & 5 & 6 \\
\hline
\end{tabular}

Source: Records Department of the Health Centre

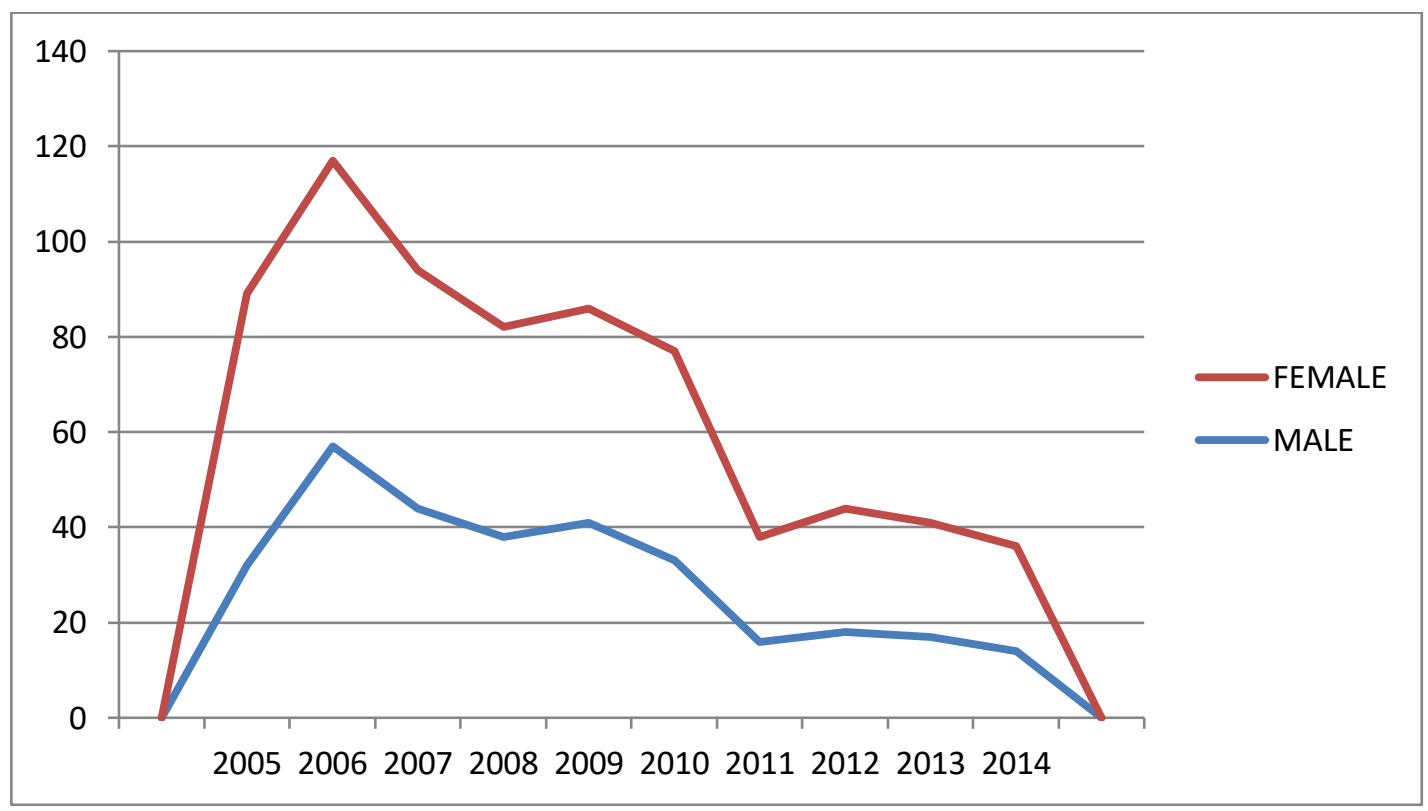

FIGURE 1 SHOWING DATA OF MALE AND FEMALE WITH REPORTED CASES OF MALARIA FROM 2005 - 2014 [ ODO -ESE HEALTH CENTRE] 
B. PREGNANT WOMEN

\begin{tabular}{|c|c|c|}
\hline YEAR (JAN-DEC) & PREGNANT WOMEN & PERCENTAGE \% \\
\hline 2005 & 16 & 11 \\
\hline 2006 & 13 & 10 \\
\hline 2007 & 14 & 9 \\
\hline 2008 & 12 & 8 \\
\hline 2009 & 11 & 7 \\
\hline 2010 & 10 & 9 \\
\hline 2011 & 12 & 11 \\
\hline 2012 & 15 & 12 \\
\hline 2013 & 17 & 14 \\
\hline 2014 & 20 & $\mathbf{1 0 0 \%}$ \\
\hline Total & $\mathbf{1 4 0}$ & \\
\hline
\end{tabular}

Source: Records Department

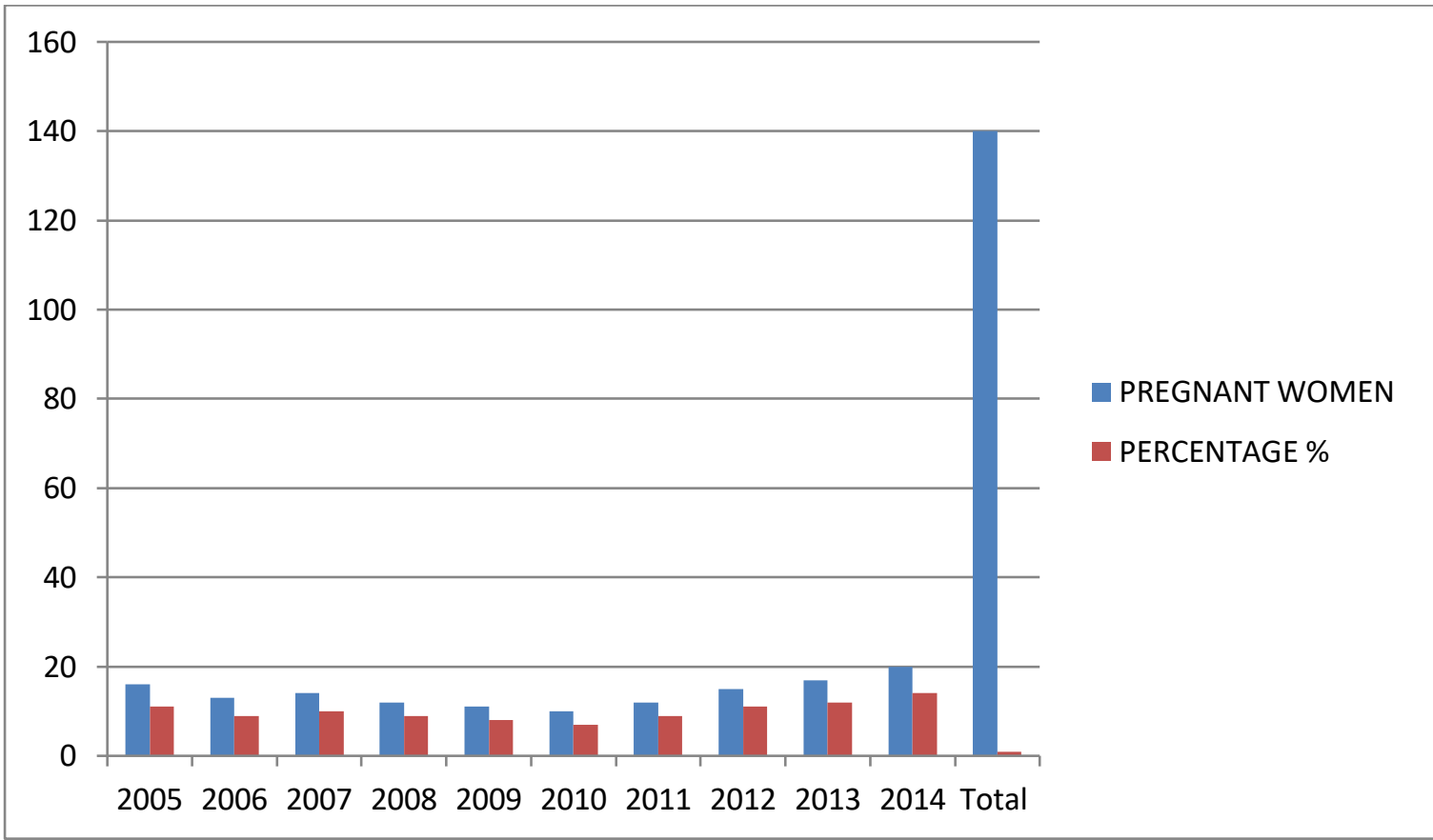

FIGURE 2 SHOWING DATA ON PREGNANT WOMEN WITH REPORTED CASES OF MALARIA FROM 2005-2014[ ODO -ESE HEALTH CENTRE]

\section{C: CHILDREN ABOVE 5 YEARS AND OTHERS}

\begin{tabular}{|c|c|c|c|c|}
\hline YEARS (JAN-DEC.) & MALE & FEMALE & PERCENTAGE (MALE) & PERCENTAGE (FEMALE) \\
\hline 2005 & 07 & 14 & 4 & 6 \\
\hline 2006 & 10 & 15 & 5 & 6 \\
\hline 2007 & 14 & 17 & 7 & 11 \\
\hline 2008 & 22 & 25 & 11 & 10 \\
\hline 2009 & 21 & 26 & 9 & 10 \\
\hline 2010 & 18 & 30 & 11 & 12 \\
\hline 2011 & 21 & 27 & 13 & 12 \\
\hline 2012 & 24 & 29 & 14 & 13 \\
\hline 2013 & 26 & 32 & 15 & 14 \\
\hline 2014 & 29 & 36 & $\mathbf{1 0 0 \%}$ & $\mathbf{1 0 0 \%}$ \\
\hline Total & $\mathbf{1 9 2}$ & $\mathbf{2 5 1}$ & & \\
\hline
\end{tabular}

Source: Records Department. 


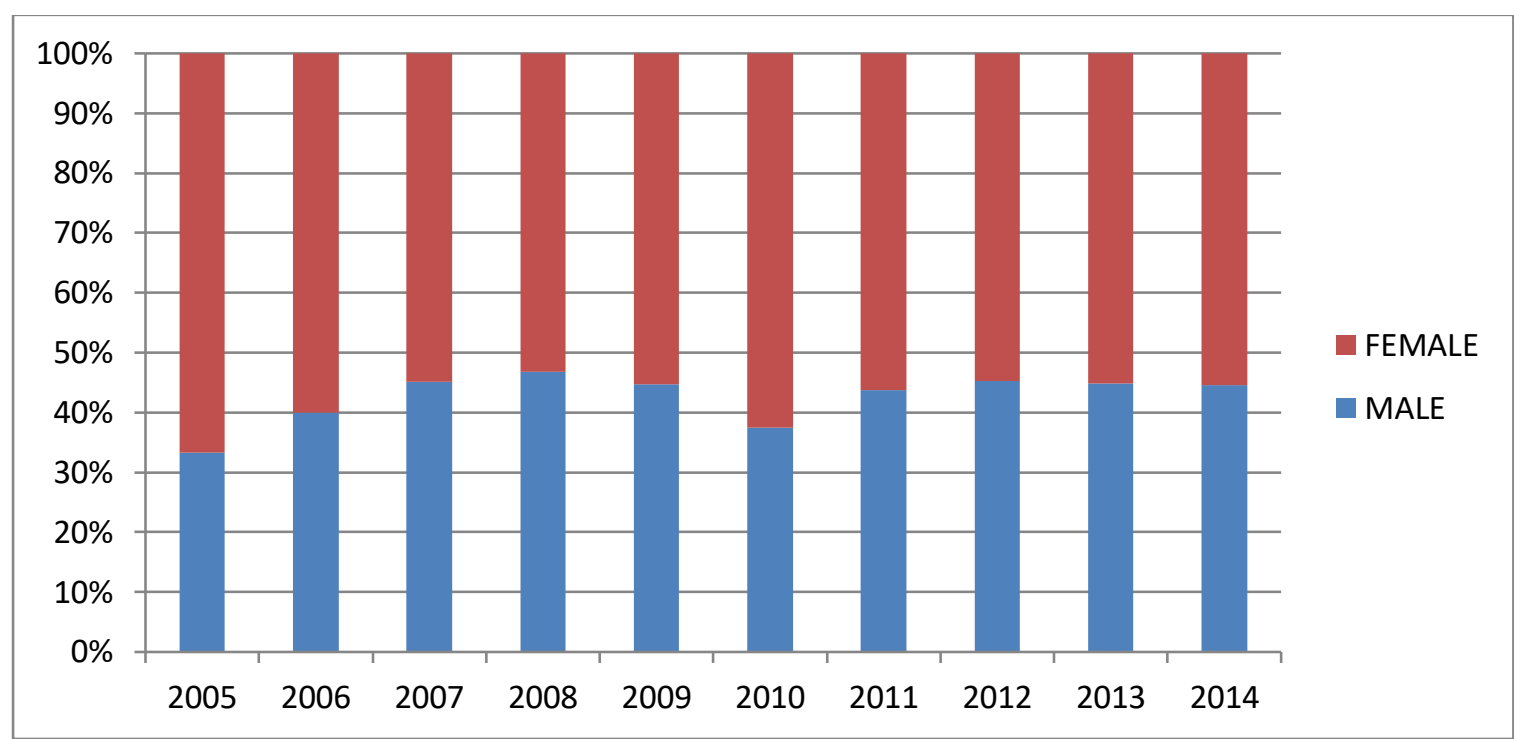

FIGURE 3 SHOWING DATA ON CHILDREN [MALE \&FEMALE] ABOVE 5 YEARS WITH REPORTED CASES OF MALARIA BETWEEN 2005 - 2011[ ODO -ESE HEALTH CENTRE]

\section{DATA RETRIEVED FROM ODO - OYE HEALTH}

CENTRES, IJERO EKITI ARE HEREBY TABULATED BELOW:

\begin{tabular}{|c|c|c|c|c|}
\hline $\begin{array}{c}\text { YEAR (JAN- } \\
\text { DEC) }\end{array}$ & MALE & FEMALE & $\begin{array}{c}\text { PERCENTAGE } \\
\text { (MALE) }\end{array}$ & $\begin{array}{c}\text { PERCENTAGE } \\
\text { (FEMALE }\end{array}$ \\
\hline 2005 & 16 & 21 & 10 & 10 \\
\hline 2006 & 18 & 22 & 11 & 10 \\
\hline 2007 & 16 & 20 & 10 & 8 \\
\hline 2008 & 14 & 17 & 8 & 9 \\
\hline 2009 & 13 & 19 & 8 & 10 \\
\hline 2010 & 14 & 21 & 8 & 11 \\
\hline 2011 & 17 & 23 & 10 & 11 \\
\hline 2012 & 19 & 26 & 11 & 10 \\
\hline 2013 & 21 & 24 & 13 & $\mathbf{1 0 0 \%}$ \\
\hline 2014 & 18 & 22 & 11 & $\mathbf{1 0 0 \%}$ \\
\hline Total & $\mathbf{1 6 6}$ & $\mathbf{2 1 5}$ & $\mathbf{1 0} \%$ & \\
\hline
\end{tabular}

Source: Records Department.

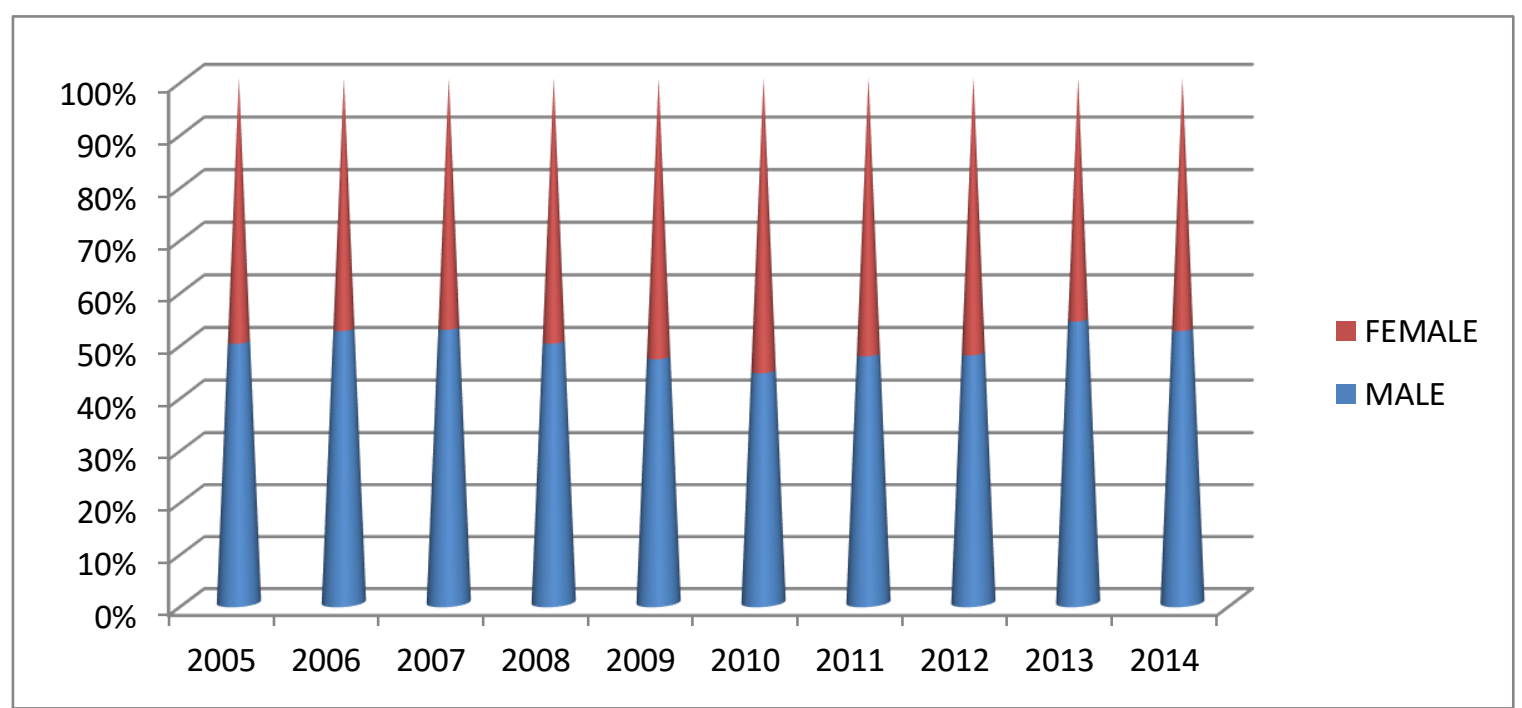

FIGURE 4 SHOWING DATA ON CHILDREN [MALE \&FEMALE] UNDER 5 YEARS WITH REPORTED CASES OF MALARIA BETWEEN 2005 - 2014[ODO - OYE HEALTH

\section{CENTRES]}


B. PREGNANT WOMEN

\begin{tabular}{|c|c|c|}
\hline YEAR (JAN-DEC) & PREGNANT WOMEN & PERCENTAGE \% \\
\hline 2005 & 14 & 8 \\
\hline 2006 & 12 & 7 \\
\hline 2007 & 19 & 11 \\
\hline 2008 & 20 & 11 \\
\hline 2009 & 21 & 12 \\
\hline 2010 & 17 & 10 \\
\hline 2011 & 13 & 7 \\
\hline 2012 & 19 & 11 \\
\hline 2013 & 22 & 12 \\
\hline 2014 & 20 & 11 \\
\hline Total & $\mathbf{1 7 7}$ & $\mathbf{1 0 0 \%}$ \\
\hline
\end{tabular}

Source: Records Department.

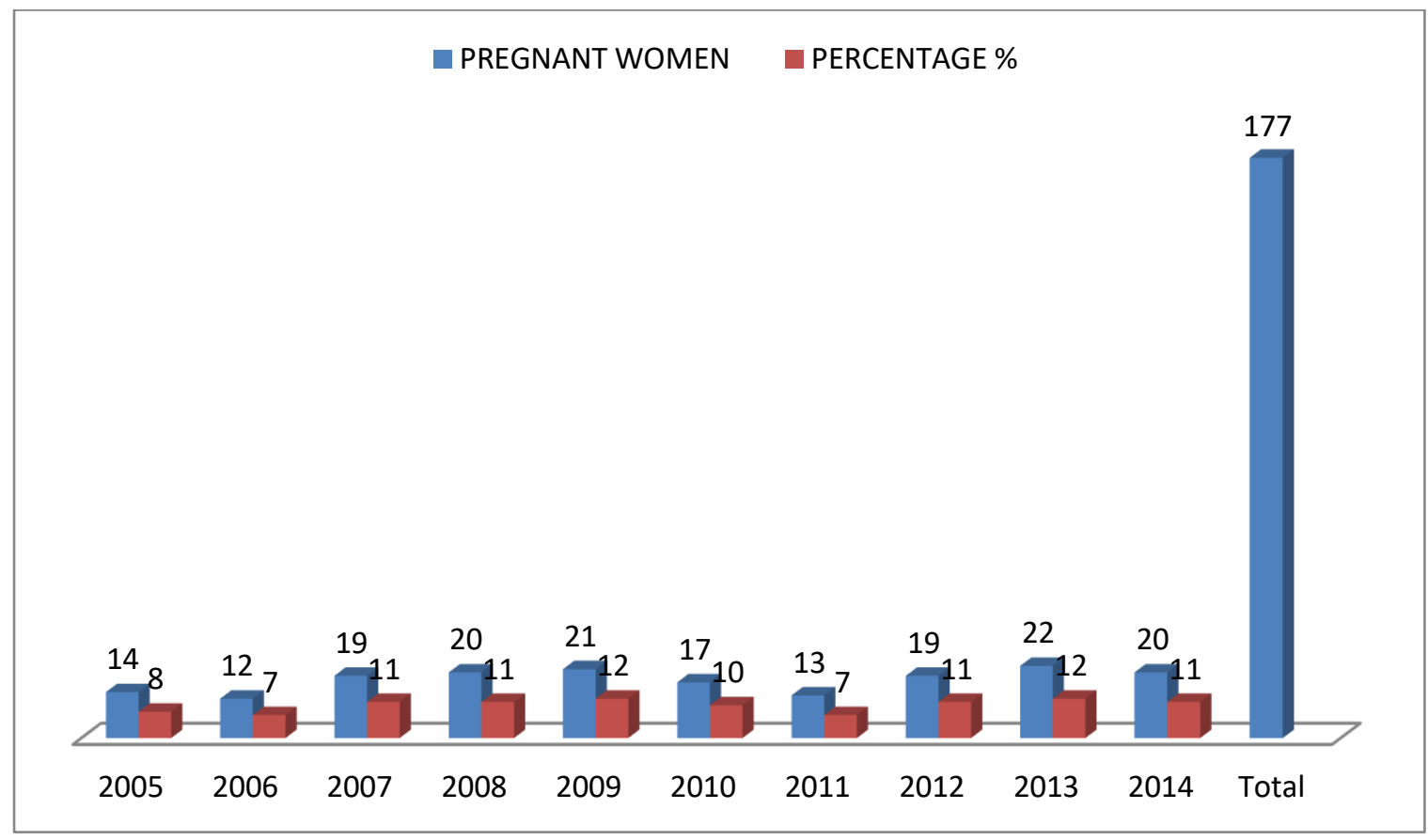

FIGURE 5 SHOWING DATA ON PREGNANT WOMEN WITH REPORTED CASES OF MALARIA BETWEEN 2005 - 2014 ODO - OYE HEALTH CENTRES

\section{C: CHILDREN ABOVE 5 YEARS AND OTHERS}

\begin{tabular}{|c|c|c|c|c|}
\hline $\begin{array}{c}\text { YEARS (JAN- } \\
\text { DEC.) }\end{array}$ & MALE & FEMALE & $\begin{array}{c}\text { PERCENTAGE } \\
\text { (MALE) }\end{array}$ & $\begin{array}{c}\text { PERCENTAGE } \\
\text { (FEMALE) }\end{array}$ \\
\hline 2005 & 10 & 15 & 7 & 9 \\
\hline 2006 & 19 & 25 & 14 & 12 \\
\hline 2007 & 9 & 20 & 7 & 9 \\
\hline 2008 & 14 & 19 & 10 & 12 \\
\hline 2009 & 18 & 25 & 13 & 7 \\
\hline 2010 & 11 & 17 & 8 & 7 \\
\hline 2011 & 9 & 14 & 7 & 13 \\
\hline 2012 & 7 & 14 & 5 & 13 \\
\hline 2013 & 21 & 26 & 15 & $\mathbf{1 0 0 \%}$ \\
\hline 2014 & 20 & 27 & 14 & $\mathbf{1 0 0 \%}$ \\
\hline Total & $\mathbf{1 3 8}$ & $\mathbf{2 0 2}$ & & \\
\hline
\end{tabular}

Source: Records Department. 


\section{DATA RETRIEVED FROM OJU-ORO HEALTH}

CENTRES, IJERO EKITI ARE HEREBY TABULATED BELOW:

CHILDREN UNDER 5 YEARS

\begin{tabular}{|c|c|c|c|c|}
\hline $\begin{array}{c}\text { YEAR (JAN- } \\
\text { DEC) }\end{array}$ & MALE & FEMALE & $\begin{array}{c}\text { PERCENTAGE } \\
\text { (MALE) }\end{array}$ & $\begin{array}{c}\text { PERCENTAGE } \\
\text { (FEMALE }\end{array}$ \\
\hline 2009 & 9 & 11 & 13 & 12 \\
\hline 2010 & 11 & 14 & 16 & 16 \\
\hline 2011 & 14 & 19 & 21 & 21 \\
\hline 2012 & 15 & 18 & 23 & 20 \\
\hline 2013 & 10 & 16 & 15 & 18 \\
\hline 2014 & 8 & 12 & 12 & 13 \\
\hline Total & $\mathbf{6 7}$ & $\mathbf{9 0}$ & $\mathbf{1 0 0 \%}$ & $\mathbf{1 0 0 \%}$ \\
\hline
\end{tabular}

Source: Records Department.

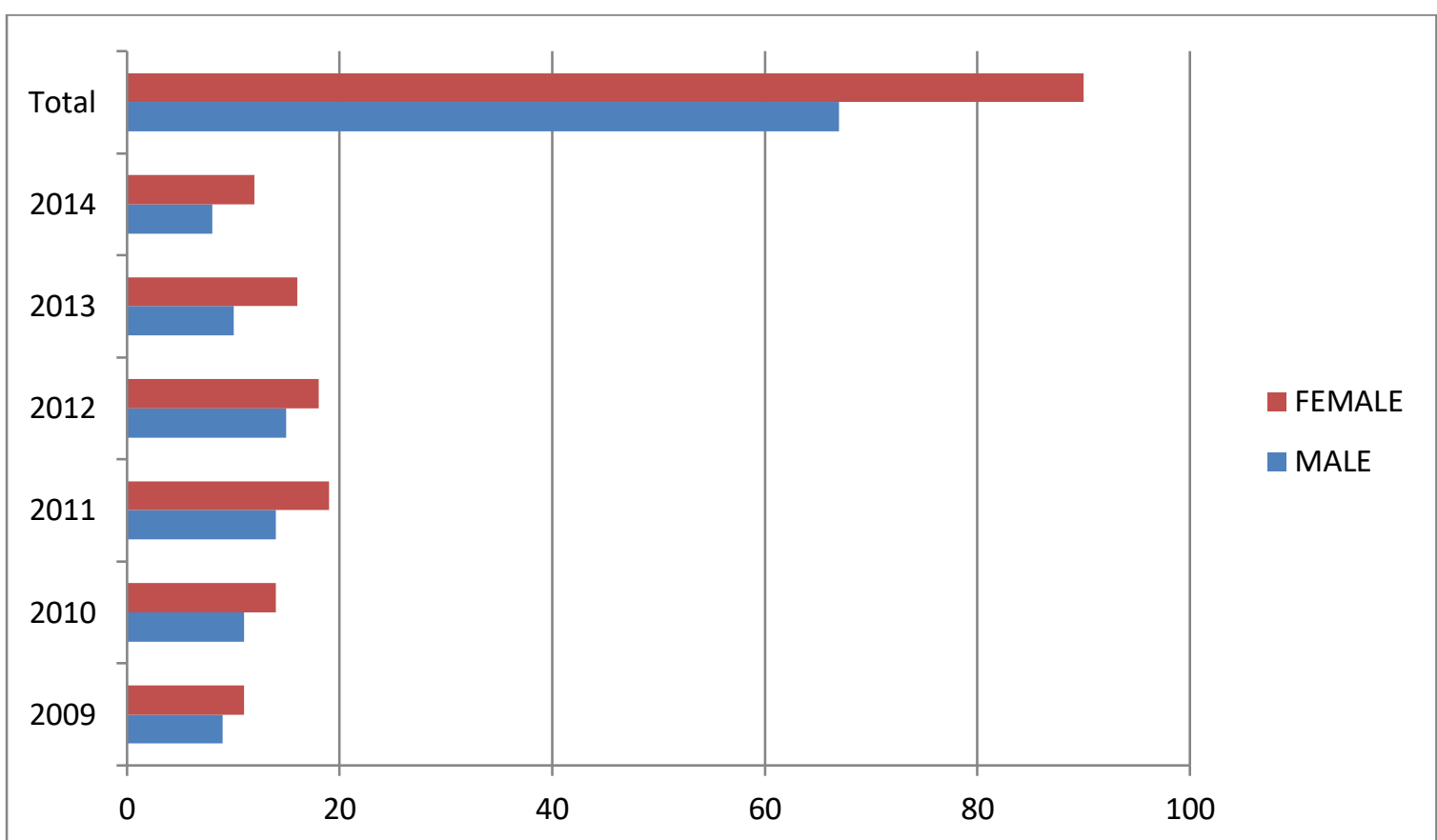

FIGURE 6 SHOWING DATA ON CHILDREN [MALE \&FEMALE] UNDER5 YEARS WITH REPORTED CASES OF MALARIA BETWEEN 2005 - 2011[OJU-ORO HEALTH CENTRE]

B. PREGNANT WOMEN

\begin{tabular}{|c|c|c|}
\hline YEAR (JAN-DEC) & PREGNANT WOMEN & PERCENTAGE \% \\
\hline 2009 & 4 & 8 \\
\hline 2010 & 5 & 9 \\
\hline 2011 & 7 & 13 \\
\hline 2012 & 16 & 30 \\
\hline 2013 & 11 & 21 \\
\hline 2014 & 10 & 19 \\
\hline Total & $\mathbf{5 3}$ & $\mathbf{1 0 0 \%}$ \\
\hline
\end{tabular}

Source: Records Department. 


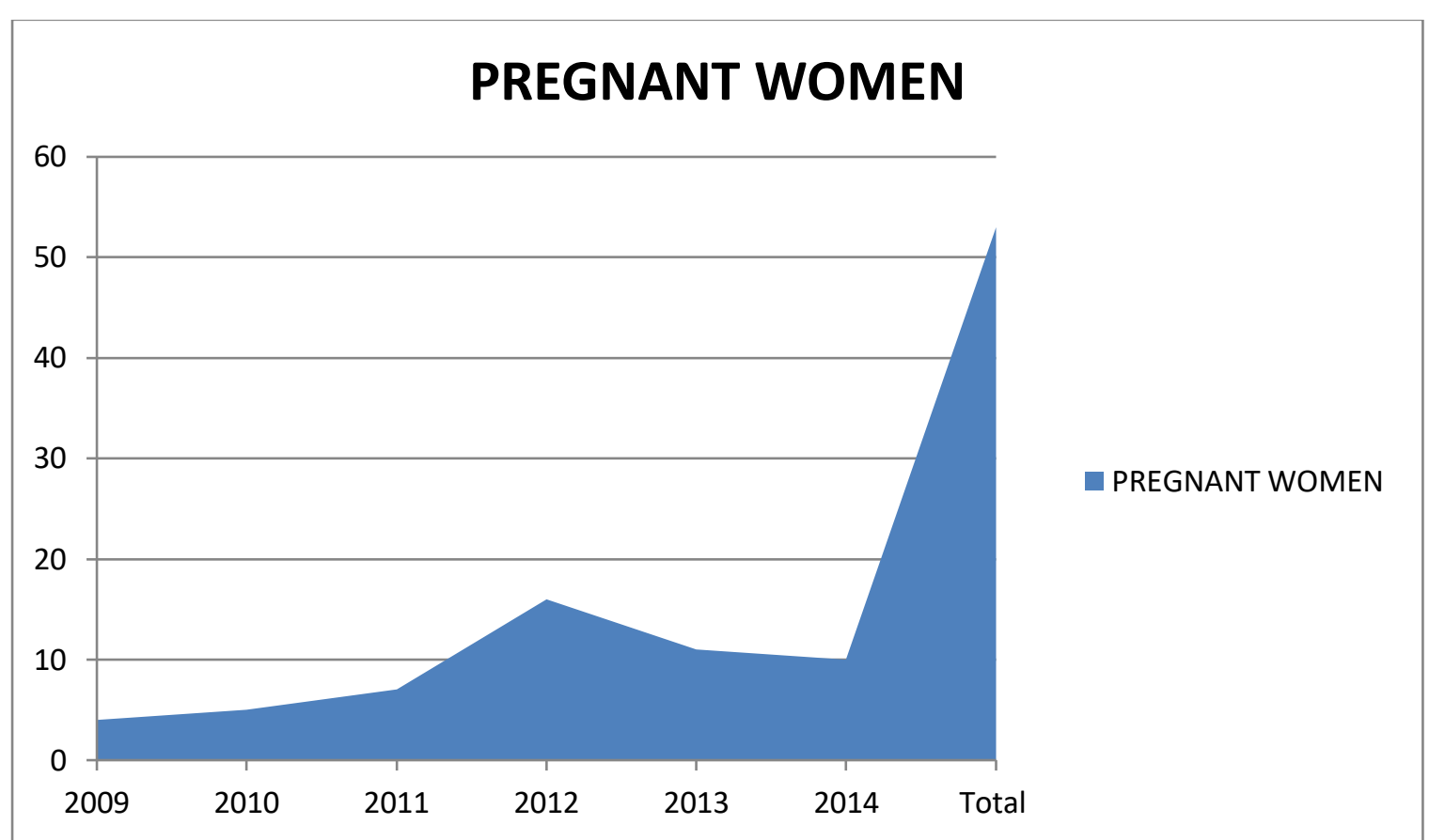

FIGURE 7 SHOWING DATA PREGNANT WOMEN WITH REPORTED CASES OF MALARIA BETWEEN 2005 - 2011 [ OJU-ORO HEALTH CENTRE]

C: CHILDREN ABOVE 5 YEARS AND OTHERS

\begin{tabular}{|c|c|c|c|c|}
\hline $\begin{array}{c}\text { YEARS (JAN- } \\
\text { DEC.) }\end{array}$ & MALE & FEMALE & $\begin{array}{c}\text { PERCENTAGE } \\
\text { (MALE) }\end{array}$ & $\begin{array}{c}\text { PERCENTAGE } \\
\text { (FEMALE) }\end{array}$ \\
\hline 2009 & 8 & 12 & $\mathbf{1 3}$ & 13 \\
\hline 2010 & 11 & 14 & 18 & 15 \\
\hline 2011 & 10 & 15 & 16 & 16 \\
\hline 2012 & 11 & 16 & 18 & 20 \\
\hline 2013 & 12 & 18 & 20 & 18 \\
\hline 2014 & 9 & 17 & 15 & $\mathbf{1 0 0 \%}$ \\
\hline Total & $\mathbf{6 1}$ & $\mathbf{9 2}$ & $\mathbf{1 0 0 \%}$ & \\
\hline
\end{tabular}

Source: Records Department.

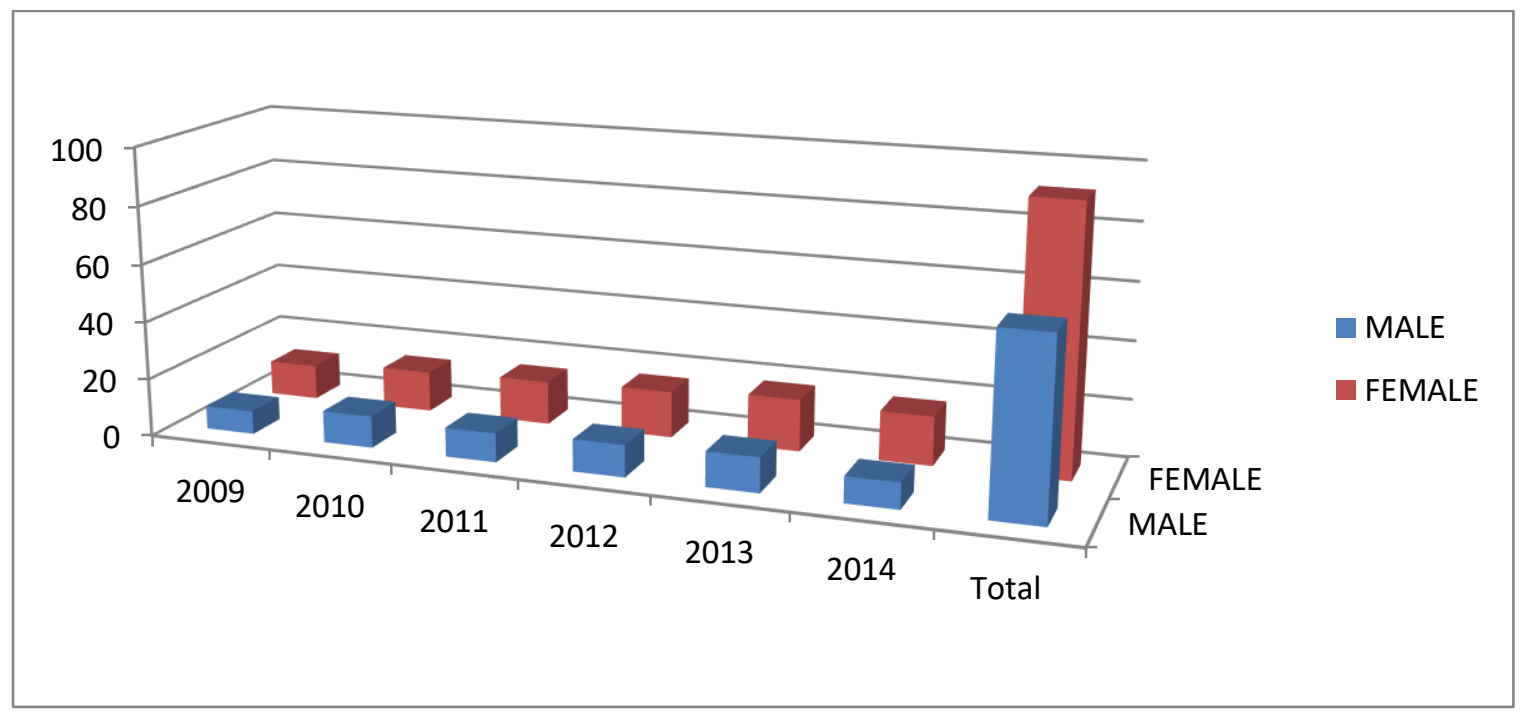

FIGURE 8 SHOWING DATA ON CHILDREN [MALE \&FEMALE] ABOVE 5 YEARS WITH REPORTED CASES OF MALARIA BETWEEN 2005 - 2011[ OJU ORO HEALTH CENTRE] 
Based on interviews carried out, observations and focus group, the following were deduced from the people in Ijero Township

- Most of Ijero residents do not appreciate the type of nets used. They prefer the mosquito bite compare to the heat and other inconvenience experienced under the nets.

- They just collect this nets because it is free but not used for the intended purpose.

- Most of them said they prefer using insecticides, mosquito coil, indoor spraying rather than using the mosquito nets.

- They patronize over the counter drug rather than visiting the clinic, health centres to complain and treat malaria.

- Men are not given the nets during mass distribution.

- People also complained about how the health workers attend to them for instance the health workers shout at them, talk to them disrespectfully.

\section{CONCLUSION}

We concluded that, attitude of users towards the use of LLITNs is against the manufacturer instruction, are also the effectiveness of LLITNs is partial due to the following reasons:

- People are complaining about the heat experienced under the nets thereby discourage the use of LLITNs

- Vector control in Ijero township strongly involves the use pyrethroids which is of course the available and recommended insecticide for LLITNs and due to these most of the nets supplied are impregnated with these chemicals which has led to resistance to the malaria vector as a result of constant use of pyrethroids.

\section{RECOMMENDATIONS}

We hereby recommend as follows:

- LLITNs should be properly packaged and labelled before distribution.

- To reduce pesticide resistance, new insect ides should be introduced to boost the efficacy of LLITNs.

- Discourage the continuous use and self-administration of pyrethroids on nets by users

- Training and Re-training program for Health workers on the sensitization of the general public on the use of LLITNS.

- Advance research on new chemicals and methods of combating Malaria..

- Identification of new insecticide that are not resistant and with the potency needed to control Malaria vector.

- And finally base on various complaint about the materials used for the production of the LLITNs which are mostly polyester, polyethylene, polypropylene. It is hereby suggested that the manufacturers should look into other materials especially cotton in the production of these nets. At the same time due to the inconveniences experienced under the net.

- These would lead to further research in the nearest future to assess the health risk associated with the use of the net looking into comparism of standard among the manufacturers.

\section{REFERENCES}

[1]. Binka F, Adongo: impact of spatial distribution of permethrin- impregnated bed nets on child mortality in rural northern Gbana. American Journal of tropical medicine and hygiene. 2009

[2]. Burkot TR: effect of untreated bed nets on the transmission of plasmodium falciparum, P. Vivax and wuchereria bancrofti in papua new Guinea. Transactions of the Royal Society of Tropical Medicine \& Hygiene. 2012; 84:773 - 779.

[3]. Chandre F et al. Modifications of pyrethroid effects associated with kdr mutation in Anopheles gambiae. Medical and Veterinary Entomology, 2000, 14:81-88.

[4]. Clarke SE et al. Do untreated bednets protect against malaria? Transactions of the Royal Society of Tropical Medicine and Hygiene, 2001, 95:457-462.

[5]. Darriet F et al. Impact of pyrethroid resistance on the efficacy of impregnated mosquito nets in the prevention of malaria: results of tests in experimental huts with deltamethrin SC. Bulletin de la Société de Pathologie Exotique, 2000, 93:131-134.

[6]. Forshaw PJ, Lister T: The role of voltage - gated chloride channel in type II pyretheriod insectiude poisoning. 2000.

[7]. Fumiya $S$ et al. The feasibility of a bed net impregnation program to enhance control of Malayan filariasis along a swamp forest in southern Thailand. Southeast Asian Journal of Tropical Medicine and Public Health, 2001, 32:235-239.

[8]. Gamble C, Ekwaru JP, ter Kuile FO. Insecticidetreated nets for preventing malaria in pregnancy. Cochrane Database of Systematic Reviews, 2006, 19 April (2):CD003755.

[9]. Georghhiou GP: The effect of agrochemicals on vector population In: pesticide Resistance in Arthropods: 2012

[10]. Hawley WA, Phillips-Howard PA, ter Kuile FO, Terlouw DJ, Vulule JM, Ombok M et al.: Communitywide effects of permethrin-treated bed nets on child mortality and malaria morbidity in western Kenya. Am J Trop Med Hyg 2003, 68: 121-127.

[11]. Hill J, Lines J, Rowland M. Insecticide-treated nets. Advances in Parasitology, 2006, 61:77-128.

[12]. Killeen GF et al. Preventing childhood malaria in Africa by protecting adults from mosquitoes with insecticide-treated nets. PLoS Medicine, 2007, 4(7):e229.

[13]. Knols BGJ, Takken W: the wide - scale use of impregnated bed nets for malaria control in Africa. Impact on mosquitoes. Proceeding of experimental and Applied Entomology, 2010 N.E.V; Amsterdam 9. 15 22

[14]. Lengeler C, Snow RW: From efficacy to effectiveness insecticide - treated bed nets in Africa. Bullettin of the World Health Organisation. 2000; 74: 325 - 332.

[15]. Mermin J et al. Effect of co-trimoxazole prophylaxis, antiretroviral therapy, and insecticide-treated bed nets on the frequency of malaria in HIV-1-infected adults in Uganda: a prospective cohort study.Lancet, 2006, 367:1256-1261. 
[16]. Najera JA: Action of pyrethroid against non-target organisms. In:

a. synthetic pyrethroid insecticides.Structures and properties. 2011

[17]. Phillips RS: Current status of malaria and potential for control. Clinical Microbiology Review. 2001; 14: 208 $-226$.

[18]. Ranson B: Identification of a point of mutation in voltage - gated sodium channel gene of Anopheles gambiae associated with resistance to PPT and pyrethroids. 2000.

[19]. Resolution WHA58.2. Malaria control. In: Fifty-eighth World Health Assembly, Geneva, 16-25 May 2005. Resolutions and decisions. Annex. Geneva, World Health Organization, 2005.

[20]. Reyburn H et al. A randomized controlled trial of insecticide-treated bednets and chaddars or top sheets, and residual spraying of interior rooms for the prevention of cutaneous leishmaniasis in Kabul, Afghanistan. Transactions of the Royal Society of Tropical Medicine and Hygiene, 2000, 94:361-366.

[21]. "Permethrin, Resmethrin, Sumithrin: Synthetic Pyrethroids For Mosquito Control". United States Environmental Protection Agency. April 17, 2002. Retrieved 2008-04-04.

[22]. Robert L. Metcalf "Insect Control" in Ullmann's Encyclopedia of Industrial Chemistry" Wiley-VCH, Weinheim, 2002. doi:10.1002/14356007.a14_263

[23]. RBM: The Global Partnership to Roll Back Malaria 2006.

[24]. Soderlund DM, Bloomguist JR: Molecular Mechanisms of insecticide resistance in: pesticide resistance in arthropods (eds RTRoush \& BE Tabashrik). 2010 Chapman \& hale, New York. PP. 58 $-96$.

[25]. Webster $\mathbf{J}$ et al. Which delivery systems reach the poor? Equity of treated nets, untreated nets and immunisation to reduce child mortality in Africa. Lancet Infectious Diseases, 2005, 5:709-717.

[26]. Woollen, Marsh: profiles of a pyrethroid insecticide following oral and dermal absorption in Man. In: proceeding of a conference on percutaneous penetration. 2007 